\title{
The logistic experience of the Brazilian Navy in humanitarian operations: the cases of earthquakes in Haiti and Chile in 2010
}

\author{
Bianca Gomes Soares Gonçalves de Mendonça ${ }^{a}$ (D), Abdon Baptista de Paula Filho ${ }^{\mathrm{a}}$ (D), \\ Adriana Leiras ${ }^{\text {** }}$ (D) \\ aPontifícia Universidade Católica do Rio de Janeiro, Departamento de Engenharia Industrial, Rio de Janeiro, RJ, Brasil \\ *adrianaleiras@puc-rio.br
}

\begin{abstract}
Paper aims: Based on the naval logistics doctrine, this paper describes and analyzes the Brazilian Navy's actions and the obstacles encountered in humanitarian operations conducted during the earthquakes in Haiti and Chile, both in 2010.

Originality: The main contribution is to report the use of Brazilian military personnel in humanitarian operations, with its distinct characteristics, serving as a basis for future works on this theme.

Research method: The research is qualitative and descriptive with an exploratory objective, based on Brazilian Navy mission reports, the legal doctrines that govern military logistics, and interview with militaries.

Main findings: The analysis of the reported cases brings lessons that the Naval Force may incorporate into possible future humanitarian operations.

Implications for theory and practice: The findings can also serve as a reference for a benchmark discussion of military operations in disaster response.
\end{abstract}

\section{Keywords}

Military logistics. Humanitarian operations. Brazilian Navy. Disaster operations.

How to cite this article: Mendonça, B. G. S. G., Paula Filho, A. B., \& Lereiras, A. (2019). The logistic experience of the Brazilian Navy in humanitarian operations: the cases of earthquakes in Haiti and Chile in 2010. Production, v. 29, e20170082. https://doi.org/10.1590/0103-6513.20170061.

Received: June 6, 2018; Accepted: Dec. 3, 2018.

\section{Introduction}

Only in 2016, 342 disasters have affected 569.4 million people affected and led to 153.9 billion dollars in economic losses (Guha-Sapir et al., 2017). According to the United Nations International Strategy for Disaster Reduction (United Nations, 2009), disaster is:

[...] a serious breakdown in the functioning of a community or society, involving widespread losses of human, material, economic and environmental resources, which exceeds the ability of the affected community or society to cope with its resources.

A disaster is the result of a combination of threats, conditions of vulnerability and inadequate capacity to reduce the negative and potential consequences of risk. Regardless of their origin or magnitude, disasters are not events that are easily manageable by routine procedures, and the interaction among stakeholders from the society and public and private sectors poses an additional challenge (Fontainha et al., 2017). 
A disaster lifecycle includes the stages of mitigation, preparation, response, and recovery (Altay \& Green IIl, 2006). The response phase has received great research attention (Leiras et al., 2014) because of the focus on life-saving and relief operations to provide immediate assistance (Eriksson, 2009).

Military involvement in humanitarian operations with its disaster response experience has played an essential role in providing support to these events. The military need to be resilient and robust to deal with the uncertainties of combat which is also beneficial in situations and environments affected by disasters (Weeks, 2007). The military employs specialized units for transport and logistics, security, construction and repair, communications, medical care, relief supplies, and human resources in disaster response (Pettit \& Beresford, 2005; Oloruntoba, 2010; Tatham \& Rietjens, 2016; Costa et al., 2017).

The primary purpose of the Armed Forces in many countries is to defend the homeland, national interests, and the maintenance of the sovereignty of the states. However, it is not unusual to observe other legal bases that support the actions of the Armed Forces, participating in activities in the humanitarian field, either in its territory or externally, in countries that request such actions (Aversa, 2011).

This paper presents an analysis of the Brazilian Navy logistics that support humanitarian operations. We present and compare the cases of two Brazilian Navy participation in humanitarian assistance operations (earthquakes in Haiti and Chile in 2010). The cases were defined according to the data availability and because they are of the same type of disaster (earthquakes) that occurred with short difference time period (January and February 2010). Based on the documents governing the Brazilian Navy and in interviews with ten militaries that participated in the two operations, the logistical aspects involved in these operations are presented.

This work aims to contribute to the development of new academic studies in the topic, besides serving as a documentary research source to support future actions that seek to improve the decisions of those that work in the logistics activities of the Brazilian Armed Forces. This alignment between academic knowledge and empirical testing is a research gap in humanitarian operations, as indicated by Leiras et al. (2014) and Behl \& Dutta (2018). Also, Heaslip \& Barber (2014) highlight of a re-evaluation and performed by the military operations in disaster response to improve performance (Costa et al., 2017).

In addition to this introductory section, Section 2 presents the research methodology. Section 3 summarizes the theoretical basis. Section 4 describes and analyzes the Brazilian Navy's performance in the cases of earthquakes in Haiti and Chile in 2010. Section 5 presents the conclusions and directions for future works.

\section{Research methodology}

The research is qualitative, descriptive and exploratory and the case study method is used (Yin, 2013) with the focus on deepening the understanding of the Brazilian Navy logistics performance in humanitarian missions. This qualitative approach was carried out empirically: investigating the phenomenon inserted in a real-life context (Yin, 2013), which means examining the real disasters situations that occurred in Haiti and Chile in 2010 relating the performance of the logistics of Brazilian Navy and its supply system in these cases.

The research is based on official documents, current norms, and interviews with ten militaries. The access to the of the 2010 earthquakes in Haiti and Chile mission reports are assured due to the official position of one of the authors in Brazilian Navy, but they are currently available under specific request for non-military personnel. The interviews are guided by a closed-ended questionnaire composed by seven questions based on a five points Likert scale (strongly disagree; disagree; do not agree or disagree; agree; totally agree), besides two open questions. The military personnel was selected for interviews due to their participation in the logistics of both disaster response operations. The interviewees have an average time of experience of 18 years.

\section{Theoretical foundation}

The humanitarian supply chain includes a broad scope of action by its agents due to the range of activities involved, such as the relationship between donors, distributors, buyers, stockpiles, transporters, buyers, and beneficiaries. The main factors that affect the humanitarian chain management are great diversity and number of actors involved; donor expectations and funding structure; the unpredictability regarding location, duration, and intensity; and scarcity and excess resources. The media are often considered as a critical factor that directly affects aid operations (Balcik et al., 2010).

The differences among business logistics, humanitarian logistics, and military logistics begin in their goals and objectives. Whereas business logistics seek to reduce costs, maximize return, and improve customer service, humanitarian logistics is meant to save lives and alleviate people's suffering in the shortest possible time 
(Van Wassenhove, 2006). The military logistics is characterized by its more technical and scientific side, in which regularity and a certain degree of process predictability require the use of tools - similar to business logistics, but it is also linked to the uncertainty and fluidity present in the war - similar to that of humanitarian logistics.

Military logistics seeks to provide resources to the Armed Forces, as estimates of needs for action with maximum combat efficiency (Brasil, 2016). According to the American Logistics Doctrine, military logistics can be defined as:

The planning and execution of troop support and movement, including aspects of military operations that deal with sizing and execution, procurement, storage, transportation, distribution, maintenance and availability of the material, acquisition or construction, maintenance, operation and provision of facilities, as well as the acquisition or supply of services.

From the analysis of disasters, one can define the factors that determine the efficiency of the military response to disasters, among which we can highlight: the adequacy of the used resources; the interoperability of military means with the broader aid efforts; the absorptive capacity of the recipient country to accommodate a massive flow of goods and people; and coordination among various institutions (civil, military, governmental, and non-governmental) (Phillips, 2011).

The use of military assets in humanitarian operations was regulated in 1994 in a collaborative effort among various countries and international organizations, culminating in the publication of the Oslo Guidelines in Oslo, Norway (Aversa, 2011).

Humanitarian assistance provided by the armed forces is essential in situations where the presence of humanitarian agencies is non-existent or insufficient or when the security environment is prohibitive, preventing access (Burkle Junior, 2005). Some assets that are quickly and efficiently deployed in response to disaster needs are often detained by the military (Oloruntoba, 2010), such as fuels, transportation and communications equipment, engineering and construction equipment, medicines, and stock of provisions such as food and water.

The organization, structure, and readiness of the Armed Forces enable the command to respond quickly, which is necessary for humanitarian action. According to Ministerial Directive No. 004 (Brasil, 2001), the Brazilian Armed Forces (aeronautics, navy, and army) should act in Civil Defense activities in a cooperative regime and, except for specific tasks coordinated by each Armed Forces, the coordination of actions will be the responsibility of the Civil Defense body with jurisdiction over the location of the incident. To perform humanitarian operations or any other work, the Armed Forces need the support of their logistics to accomplish their missions.

Military aid is typical in many humanitarian actions and can offer the most diverse benefits for these efforts since the military tends to be more operationally focused on carrying out activities of this nature (Weeks, 2007). Table 1 presents the operational activities that can be performed by the military in humanitarian operations.

Table 1. Activities carried out by the military in humanitarian actions (Leaning et al., 1999).

\begin{tabular}{|c|c|}
\hline Activity & Description \\
\hline Safety & $\begin{array}{l}\text { Protection of storage sites, the establishment of security points, maintenance of an armed presence with credibility } \\
\text { to reduce violence and robberies. }\end{array}$ \\
\hline Transportation and Logistics & $\begin{array}{l}\text { Ability to transport resources and people efficiently, in addition to providing materials and equipment throughout } \\
\text { the process. }\end{array}$ \\
\hline Construction and Repair & Ability to build or repair essential elements for activities such as roads, airstrips and support points. \\
\hline Control and Communication & $\begin{array}{l}\text { Use of sophisticated communication systems. Strong organizational capacity, facilitating the control of activities. } \\
\text { Ability to quickly organize and respond to contingencies that may occur. }\end{array}$ \\
\hline Medical support & Prepared professionals and qualified health teams, evacuation plans and disease control. \\
\hline Special Forces & $\begin{array}{l}\text { Professionals trained to have the first contact and act between the military and the population in general; } \\
\text { encompasses specialists in transportation, law, business, communication, and health, among other essential elements. }\end{array}$ \\
\hline Preparation & Ability to act, train and control efficiently, to respond quickly to calamity. \\
\hline
\end{tabular}

In Brazil, military logistics are conditioned by the following legal bases: the Federal Constitution of 1988 (Brasil, 1988), Complementary Law 97/1999 (Brasil, 1999), Ministerial Directive n (Brasil, 2001), the Defense Logistics Policy (Brasil, 2006), the National Defense Policy (Brasil, 2013), the Military Logistics Doctrine (Brasil, 2016), the National Defense Strategy (Brasil, 2003) and the White Paper on National Defense (Brasil, 2012).

The National Defense Strategy (Brasil, 2013) set goals to ensure that National Defense objectives could be achieved. The National Defense Policy (Brasil, 2013) considers that in order to broaden Brazil's projection in the world context and reaffirm its commitment to the defense of peace and cooperation between people, the country must improve the preparation of the Armed Forces to carry out increasing responsibilities in humanitarian 
actions, in peace missions under the aegis of multilateral organizations, in accordance with national interests. The Defense White Paper (Brasil, 2012) directs that Brazil must consolidate governance mechanisms geared to global peace and security and the well being of humanity.

For the Military Logistics Doctrine (Brasil, 2016), which is the norm regulating logistic activity by the Brazilian Armed Forces, logistics provides the human resources, materials, and services necessary to satisfy their needs and enable them to carry out their activities in times of war or peace.

In line with the Military Logistics Doctrine (Brasil, 2016), the Brazilian Navy adopts the following definition for naval logistics (Brasil, 2003):

The military logistics branch concerning the means, officers, and organizations of command, communications and support staff employed by the Navy to meet the needs of naval forces.

For the Brazilian Navy, the Navy Basic Doctrine - DBM (Brasil, 2014) still conditions its logistics, which is the document that formally serves as a reference and basis for all other doctrinal documents that guide the Navy's performance. For DBM, the effectiveness and effectiveness that the Force seeks in the actions depend on the combination of all the logistic functions described in the Navy Logistics Manual (Brasil, 2003): Procurement; Maintenance; Rescue; Health; Human Resources; Transport and Engineering.

In the Navy, the logistics functions of Procurement, Human Resources, and Health have their structured support systems - the Supply System, the Personnel System, and the Health System, respectively.

According to the Logistics Manual (Brasil, 2003), the logistics cycle follows three stages: needs assessment; procurement and distribution. The needs assessment phase is performed by the users of the Navy systems and begin the entire cycle. It occurs when the agents who carry out tasks related to logistics answer the following questions: what is necessary? How much is needed? When will it be necessary? Where will it be required? And what is more important?

The procurement phase is usually carried out by the Navy Procurement Center in Rio de Janeiro, whose purpose is to promote or procure and purchase the material belonging to the supply line of the Navy Supply System. However, there is no institutional obligation for all procurement to be carried out by this Procurement Center. The procurement phase is carried out in a decentralized manner, making it challenging to manage demand and inventory levels.

The distribution phase occurs between two elements, a support organ, which is not necessarily a procurement body and a receiving agency, which is the military organization that consumes or uses.

The Force does not treat the Supply as a specific logistics function, making it more comprehensive, integrating the logistics function supply, part of the logistics function transport, also, to relate to the maintenance logistics function.

Another condition for logistics in the Navy is the Navy Supply Planning Directive (DIPLAB). Inserted in the DIPLAB, and applied to enable adequate supply support to the operational means, a system called Operational Priority of Supply (PROA) aims to make feasible the effectiveness of supplying supplies that are necessary for the fulfillment of any mission of the Brazilian Navy, with due priority. It is an attempt to improve the logistics aspects considering the available resources.

It is worth mentioning that any mean that is requested to take part in Navy humanitarian operations will have top priority over any other.

\section{The Brazilian Navy's performance in humanitarian operations - the cases of earthquakes in Haiti and Chile in 2010}

This section presents the performance of the Brazilian Navy in the cases studied.

\subsection{Earthquake in Haiti in 2010}

Many environmental, political and social factors make Haiti extremely vulnerable to disasters and low resilience.

Between 7:30 p.m. and 8:00 p.m. on January 12, 2010, Brasilia time, twelve earthquakes with an epicenter located $10 \mathrm{~km}$ SW reached Port-au-Prince - Capital of Haiti. These tremors left about 300,000 dead in the nation considered the poorest in the continent (Aguilar, 2012). The earthquake that struck Haiti had a 7.3 of magnitude on the Richter scale, and several minor shocks hit the same region in subsequent days, including another 5.9 earthquake on January 20.

The earthquake affected the country's economic, administrative, political and community center, that concentrates 66\% of the country's Gross Domestic Product (GDP) and 39\% of the national population located 
in the city of Port-au-Prince, the capital of the state and its surroundings (Organizacion Panamericana de la Salud, 2010).

Table 2 briefly depicts how Haiti was soon after the earthquake of 2010 .

Table 2. Summary of damages and losses in the 2010 Haiti earthquake (Haiti Grassroots Watch, 2011).

\begin{tabular}{lc}
\hline Dead people & Approximately 300,000 \\
Injured people & 300,572 \\
Houses collapsed or severely damaged & $1,883,830$ \\
Destroyed hospitals & 30 \\
Destroyed schools & 3,978 \\
Destroyed infrastructure & $60 \%$ \\
Estimated economic losses & $66 \%$ of GDP \\
\hline
\end{tabular}

The Brazilian Navy has a Marine Base in Haiti for the development of actions related to the United Nations Mission for the Stabilization of Haiti (MINUSTAH), which was installed in Haiti in 2004. According to the Navy Report on Humanitarian Aid to Haiti (Brasil, 2010a), the health teams of the Marine Corps Operational Group were activated, participating in the care of victims of the collapses of the Hotel Christopher, headquarters of the mission, and the National Fort - buildings located in the capital of the country. Due to a large number of victims resulting from the earthquake, the number of doctors and nurses already working in this Operating Group was considered insufficient to meet the needs.

According to internal military release No. 03 (Brasil, 2010e), on January 13 a meeting was held at the Brazilian Ministry of Defense. As a result of this meeting, the General Navy Staff (EMA) - which is the General Oversight Organ of the systems that operate in the logistics functions of supplies, human resources and health -, informed the Marine Command Command (CGCFN), Operations Command Navais (ComOpNav) and General Directorate of Personnel of the Navy (DGPM) on the request of support of emergency supply of bottled water, operational ration and health material.

The initial demands arising from the post-earthquake were not planned, had no established inventory policies, with replenishment points and defined levels of security to ensure continuity of the logistics chain.

On January 15, 2010, the General Staff of Defense ordered the deployment of a Navy Campaign hospital to Port-au-Prince. It would be the first time that the Navy's field hospital would be used (Brasil, 2010a).

On January 16, 2010, the Italian Navy offered the joint employment to the Brazilian Navy to work on the humanitarian mission. Military of the Navy and Civil Servants of the Brazilian Ministry of Health act aboard the aircraft carrier "CAVOUR," of the Italian Navy. The shipment occurred on January 28 and contributed to the health logistics function could be activated (Vilela, 2015).

According to the internal military release of January 28, 2010 (Brasil, 2010f), in the ltalian aircraft carriers were also shipped Brazilian Navy helicopters of the Super Puma and Esquilo types, which contributed to the transportation of personnel and material, search and rescue and support to troops on land. The helicopters allowed the military to operate in situations where the port was destroyed and the roads severely damaged.

On January 17, the Brazilian Navy expressed to the Defense General Staff the need to establish a Logistics Support and Procurement Office in the Dominican Republic to support Brazilian troops in Haiti and provide humanitarian aid. The Brazilian Navy also participated in its capacity to prepare an adequate force for security missions (Brasil, 2010a).

The estimated cost and investment of the Navy mission for 60 days in Haiti totaled R\$ 61,047,598.00 (Brasil, 2010a). This amount did not consider the payment of the workforce, related to the sending of another 201 members, in addition to the 215 Navy militaries already enrolled in the mentioned mission.

On January 22, the Ministry of Defense determined that the Brazilian Navy would designate one of its amphibious means to promote resupply to the mission, and could include humanitarian aid in that environment as well (Brasil, 2010a). The ship initially designated by the Navy was the Landing Ship of Combat Cars "Almirante Sabóia." On January 25, the Navy participated to the Ministry of Defense that the ship, the cargo initially requested and the personnel was ready to be shipped (Brasil, 2010a). Between January 27 and 31, the ship was loaded. There was a concern to carry out the shipment of the material in a manner considering the independence of external support for the landing. Cargo was carried out on pallets and containers, making the operation faster. On February 17, the ship carried 209.1 tons of humanitarian aid arrived in Haiti. From the day that the earthquake occurred until the arrival of the first ship with humanitarian support, more than a month passed (Brasil, 2010a).

Following the humanitarian logistical flow, the "Garcia D'Avila" ship traveled to Haiti on February 28, carrying about 200 tons on board of aid material, which were shipped in the cities of Rio de Janeiro, Recife and Fortaleza. In addition to humanitarian aid, material for resupplying Brazilian troops, such as vehicles (truck, ambulance and armored), and generators of energy and ammunition (Brasil, 2010a) was also transported by this ship. 
The Brazilian Navy participated actively in the humanitarian aid actions developed by the Brazilian government in that country. Due to the precarious port conditions found in Port-au-Prince, unloading of any supplies on Haitian beaches was considered a challenge. Because it possesses ships with amphibious capacity, characteristic that usually, a merchant ship does not own, a warship of the Brazilian Navy was used. This type of vessel has a large cargo capacity, and its unloading is differentiated, with no port structure necessary or requiring external support, as they have cranes with different capabilities, as well as bow and stern ramps.

The Brazilian aircraft carrier operated jointly with an ltalian aircraft carrier in missions mainly for the evacuation of the wounded, as well as others, such as transportation of personnel and material, search and rescue and support to troops on land. The team worked with ltalian doctors already embarked on medical rescue procedures for victims rescued by ground helicopters. The Italian ship has an emergency hospital with thirty-five beds, eight of them in Intensive Care Units (Vilela, 2015; Brasil, 2010a).

\subsection{Earthquake in Chile in 2010}

The Chilean territory is exceptionally vulnerable to natural disasters, mainly because it is located on the edge of a tectonic plate very close to the jointness of the South American and Nazca plates. Therefore, that position makes the country have many reasons to worry about the occurrence of disasters: tsunamis, volcanic eruptions, floods and, above all, earthquakes that continuously threaten Chileans (Yanez, 2012).

Forty-seven days after the Haiti disaster, another earthquake hit Chile. The earthquake covered an area of 700 kilometers, from the city of Temuco to Santiago, devastating a large part of the towns of Constitución, Concepción, Cobquecura and the port of Talcahuano. The regions that were most affected suffered significant damage to their roads, bridges, airports, ports, public services, and communication networks. It was considered the second strongest earthquake in the country and one of the five highest registered worldwide (8.8 on the Richter scale) (United States Geological Survey, 2011).

The earthquake that hit the Chilean territory was followed by a tsunami that struck at least six regions of the country (more than half of the national land), including its principal metropolis, as well as dozens of medium-sized cities and numerous smaller coastal and inland towns of the country (United States Geological Survey, 2011). The most severe damage occurred along the coast and parts of the central valley of Chile. The primary industries in the region were deeply affected (fishing, shipping, mining, refineries, forestry, winemaking, and agriculture).

The consequences of these events have caused substantial infrastructure losses in areas near the epicenter. There was a total outage of electricity from the area covered by the Central Interconnected System, which supplies power from the city of Taltal, in the region of Antofagasta, to the Big lsland of Chiloé. In the absence of electricity, the country remained without communication in the fixed and cellular network, producing a long pause in radio station communications. Potable water systems, sewage networks, and wastewater discharges and treatment plants in urban and rural areas were affected (United States Geological Survey, 2011).

Due to the magnitude of the disaster, a massive workforce was employed throughout the country on the occasion of relief to be provided to those affected. This workforce presented different experiences and was adequately distributed according to the need. Several national, international and non-governmental organizations were present in the earthquake that struck Chile, including several rescue groups, civilian and military institutions from friendly countries, including Brazil (United States Geological Survey, 2011; Organizacion Panamericana de la Salud, 2010).

Humanitarian aid was provided to Chile through facilities and health personnel, as well as military hospitals. In most cases, the Chilean military ensured the safety of these facilities and made the necessary coordination with the health authority of the region. Table 3 presents a summary of the damages and losses for Chile in the earthquake accompanied by the tsunami of February 27, 2010.

Table 3. Summary of damages and losses in the 2010 Chile earthquake (United States Geological Survey, 2011).

\begin{tabular}{lc}
\hline Dead people & 521 \\
Missing people & 56 \\
Houses collapsed or severely damaged & 370,000 \\
Destroyed hospitals & 73 \\
Destroyed schools & 3,049 \\
Destroyed infrastructure & 221 \\
Estimated economic losses & $17 \%$ of GDP \\
\hline
\end{tabular}


In Chile, international humanitarian aid was provided in a complementary way to the nationals who were already working. The Brazilian Navy participated in the assistance to Chile by sending a Campaign Hospital (HCamp) to work in emergency relief. The health unit was mobilized in 48 hours and transported to the scene of the catastrophe by Brazilian Air Force (FAB) aircraft, on six flights of the "Hercules" aircraft (Vilela, 2015).

This field hospital was installed in a peripheral region near the city of Santiago, called Cerro Navia, and counted on a total of 102 Brazilian soldiers, among doctors and professionals from other areas of health support. The Campaign Hospital that was used in Chile could perform about 400 daily appointments and had autonomy to operate for thirty days, with all kinds of supplies that were needed. This hospital conducted more than 12,000 visits in 41 days of operation in the country (Brasil, 2010b; Pinto, 2010).

\subsection{Comparison of the two events}

Although the intensity of the earthquake that hit Chile exceeded the magnitude of the one that hit Haiti on the Richter scale, the country presented itself much better prepared (Vilela, 2015; Yanez, 2012). Overall response to the Haiti earthquake was considered worse by the interviewees when compared to the response to the earthquake in Chile due to the fact that Chile was more organized and prepared to deal with earthquakes (needs were well specified).

When comparing the actions undertaken by the Brazilian Navy and the type of support required in the two events, it is noted that the degree of preparation of Chile reflected in a smaller dimension for the required assistance. In Haiti, a more significant amount of workforce was needed, and also a higher availability of the military organizations involved, demanding from the Force a more elaborate logistics performance.

There are similarities and differences in the two cases. For example, in both cases, there were difficulties in needs assessment due to the generalized chaos found in the sites. Table 4 presents a brief comparison of the two earthquakes and the performance of the Brazilian Navy.

Table 4. Comparison between the two events.

\begin{tabular}{lcc}
\hline & Haiti & Chile \\
\hline Number of dead people & 300,000 & 521 \\
Estimated economic losses & $66 \%$ of GDP & $17 \%$ of GDP \\
Quality of buildings & Bad quality & Appropriate buildings \\
Area & Atlantic & Pacific \\
Magnitude (Richter scale) & 7.3 & 8.8 \\
Depth of the Epicenter & $10 \mathrm{Km}$ & $35 \mathrm{Km}$ \\
Tsunamis & No & Yes \\
Presence of Brazilian military personnel at the & Brazilian contingent installed in the country & Without the presence of military personnel \\
time of the disaster & & 102 \\
Number of Brazilian Navy members working on & 900 & Campaign hospital facility \\
humanitarian aid & &
\end{tabular}

In the case of Haiti, according to the mission reports and also mentioned by two interviewees, the fact that a military contingent already was in the country was helpful for the Navy to verify demand more accurately, facilitating the humanitarian aid that was to be provided, making this action faster and consequently more efficient. However, the interviewees do not agree or disagree that the existing Brazilian Navy base in Haiti before the earthquake and the creation of the Office of Logistical Support (Crisis Office) after the earthquake were considered differential of the Haiti response operation, when compared to the operation of Chile's response (average of 3.1 on a 1 to 5 likert scale). They also do not agree or disagree when asked whether collaboration between national and international organizations and agencies was greater in responding to the Haitian disaster than in responding to the Chilean disaster (also average of 3.1 on a 1 to 5 Likert scale).

In the Navy's supply sector, the need to meet formal and legal aspects of procurement was considered a point of delay. Budgetary issues also arose for payment of the material that would be used to help those in need. The execution of bidding procedures also caused delays (Brasil, 2010d). The norms for the execution of the supply of the mission means did not contemplate clearly and objectively how the supply should occur in humanitarian crises (Brasil, 2010d). Therefore, providing a bottleneck in management among the stakeholders involved in the supply process. When asked whether bureaucratic activities, budget issues, bidding, and other formal aspects were considered as obstacles to response operations to a greater extent in the Haitian disaster than in the Chilean operation, all respondents strongly agreed (average of 4.2 on a 1 to 5 Likert scale). 
When the Brazilian Navy needed to activate the logistic sectors that would be necessary for the humanitarian operation in Haiti, the Force did not have in practice a defined known system for all its divisions. The logistic cycle adopted by the Force was compromised in this event because those involved could not answer the raised questions, taking the time or could not identify which roles fit each one of them.

In the case of Chile, the country's high building codes saved many lives during the 2010 earthquake and are probably significant factors in the country's low mortality rates in similar disasters (Mora \& Brain, 2013).

On March 17, representatives of the Ministry of Health of Chile visited the facilities of the Campaign hospital (HCamp) used by the Brazilian Navy. The delegation visited the various huts of HCamp, noting the quality of care and patient satisfaction in the care provided by the Brazilian health team to those in need (Brasil, 2010c).

Initially, the field hospital would be installed in the city of Concepción, one of the most affected by the tragedy, but moments before the take-off of the Brazilian Air Force aircraft transporting the hospital; it was decided to install it in the Cerro Navia region outskirts of Santiago. The Cerro Navia had four large hospitals destroyed, presenting a greater need for medical performance (Vilela, 2015). This decision change evidences the importance of the logistical flexibility required to carry out this type of operation, while at the same time highlighting the weaknesses in strategic planning.

The tents used to compose the Brazilian Campaign Hospital installed in Chile presented themselves unsuitable for the cold climate found in the country.

In fact, respondents agree or fully agree (average of 4.7 on a 1 to 5 Likert scale) when asked if the Chilean team was better prepared when compared to Haiti's staff to meet post-disaster needs and minimize difficulties (demand uncertainty, inventory policies, replenishment points, and logistics flow of the operation).

\section{Conclusions}

Humanitarian operations require special planning and an enormous level of flexibility to make the logistics effort as efficient as possible.

This study presented an analysis of military operations, more specifically of the Brazilian Navy in two cases of humanitarian operations: the earthquakes in Haiti and Chile in 2010. First, a bibliographic review of military and civil concepts and doctrines was conducted. Then, the humanitarian activities carried out by the Navy in the two events were described. From this study, it is presented the performance of Navy logistics, in light of the conditioning documents, legal and regulatory bases, and interviews with the military.

The Brazilian Navy needs to anticipate the minimum needs for disasters, as it does for the regular combat scenarios in its conflict simulations. This anticipation is important o allow a logistic forecast that can contribute significantly to a solution before the disaster occurs, making the application of what is currently proposed by the PROA system more efficient within the scope of the Brazilian Navy, and allowing the incorporation of improvements in the management processes.

Regarding the procurement processes related to what is used in humanitarian missions, the need for proposals and initiative of new laws is reinforced, which will make the actual Brazilian legal diplomas more flexible, enabling higher efficiency. Currently, procurement of supplies to be used in the provision of humanitarian aid does not have a statutory requirement so that these can be carried out without due process of bidding, and this requires a considerable amount of time, a valuable factor in these situations.

This research also addressed the need for better communication among the stakeholders who work in the logistics of the Navy. The Navy alternates between two forms of the supply system, the decentralized form, and the centralized form. However, this last type though can be an operational advantage of flexibility, at first, in the second moment, can lead to a considerable waste of time and public resources. And this happens precisely in operations of the type that have been dealt with here, the humanitarian operations.

There is still space for discussion of the actions of the Armed Forces in humanitarian efforts in the academic sector or the military sector, with following the analysis of the role of the logistics of the Brazilian Armed Forces, aiming to consolidate the results in the Military Doctrine. The Navy has to strengthen its role internally and to apply the lessons learned in the case of events similar to those present in this paper. Studies that consider better preparing its stakeholders so that they can act together in advance to the challenges of that individual demand of the disaster scenario are also need.

A challenge, coming from the scenario and not from the military, is the ability to determine the extent to which the military used in the disaster response should continue to assist the region affected by the tragedy. This difficulty also permeates the other assisting agencies and needs further studies. 


\section{Acknowledgements}

Coordination for the Improvement of Higher Education Personnel (CAPES) [88887.091739/2014-01 - Finance Code 001] and Foundation for Support of Research in the State of Rio de Janeiro (FAPERJ) [203.178/2016].

\section{References}

Aguilar, S. (2012). Emerging power, humanitarian assistance and foreign policy: the case of Brazil during the earthquake crisis in Haiti. International Journal of Humanities and Social Science, 2(19), 93-101.

Altay, N., \& Green 111, W. G. (2006). OR/MS research in disaster operations management. European Journal of Operational Research, 175(1), 475-493. http://dx.doi.org/10.1016/j.ejor.2005.05.016.

Aversa, C. E. M. (2011). A arquitetura internacional para o apoio ao Haiti no pós-terremoto e a participação de forças militares nessa operação (Monografia). Escola Superior de Guerra, Rio de Janeiro. Retrieved in 06 June 2018, from http://www.esg.br/images/ Monografias/2011/AVERSA.pdf

Balcik, B., Beamon, B. M., Krejci, C. C., Muramatsu, K. M., \& Ramirez, M. (2010). Coordination in humanitarian relief chains: Practices, challenges and opportunities. International Journal of Production Economics, 126(1), 22-34. http://dx.doi.org/10.1016/j.jpe.2009.09.008.

Behl, A., \& Dutta, P. (2018). Humanitarian supply chain management: a thematic literature review and future directions of research. Annals of Operations Research, 1-44. https://doi.org/10.1007/s10479-018-2806-2.

Brasil. (1988, October 5). Constituição da República Federativa do Brasil de 1988. Diário Oficial da República Federativa do Brasil.

Brasil. (1999, June 9). Lei Complementar nº 97, de 9 de Junho de 1999. Dispõe sobre as normas gerais para a organização, o preparo e o emprego das Forças Armadas. Diário Oficial da República Federativa do Brasil.

Brasil, Ministério da Defesa. (2001, June 29). Diretriz Ministerial no 04/2001. Emprego das Forças Armadas em Defesa Civil, de acordo com o Decreto $n^{\circ}$ 3.466, de 17.05.2000 que aprova a Estrutura Regimental do Ministério da Defesa à luz da Lei Complementar no 97, de 9 de junho de 1999, cabendo ao MD emitir diretrizes para a participação das Forças Armadas nas atividades relacionadas com a Defesa Civil. Diário Oficial da República Federativa do Brasil.

Brasil, Estado Maior da Armada. (2003). EMA-400 - manual de logística da marinha (2. rev.). Brasília: Marinha do Brasil.

Brasil, Ministério da Defesa. (2006, December 29). Portaria Normativa n. 1890 de 23 de junho de 2016. Dispõe sobre a Política de Logística de Defesa (1. ed.). Brasília: Secretaria de Ensino, Logística, Mobilização, Ciência e Tecnologia.

Brasil, Marinha do Brasil. (2010a). Marinha participa de ajuda humanitária ao Haiti (NOMAR, no. 813, p. 6-7), Brasília: Centro de Comunicação Social da Marinha.

Brasil, Marinha do Brasil. (2010b). Hospital de Campanha da Marinha presta atendimento às vítimas do terremoto no Chile (NOMAR, no. 815, p. 3), Brasília: Centro de Comunicação Social da Marinha.

Brasil, Marinha do Brasil. (2010c). Hospital de campanha completa serviço no Chile (NOMAR, no. 816, p. 6), Brasília: Centro de Comunicação Social da Marinha.

Brasil, Ministério da Defesa. (2010d). Relatório de ajuda humanitária da marinha no Haiti (Carta externa; no. 40-478/2010). Brasília: Secretaria de Ensino, Logística, Mobilização, Ciência e Tecnologia.

Brasil, Ministério da Defesa. (2010e). Terremoto no Haiti (Comunicado de Imprensa; no. 3). Brasília.

Brasil, Ministério da Defesa. (2010f). Operação conjunta entre as marinhas do Brasil e da Itália no Haiti (Comunicado de Imprensa). Brasília.

Brasil, Ministério da Defesa. (2012). Livro branco de defesa nacional - LBDN. Brasília.

Brasil. (2013, September 25). Decreto Legislativo $n^{\circ}$ 373. Política Nacional de Defesa. Diário Oficial da República Federativa do Brasil.

Brasil, Estado Maior da Armada. (2014). EMA-305- doutrina militar naval (2. rev.). Brasília: Marinha do Brasil.

Brasil, Ministério da Defesa. (2016, June 23). Portaria Normativa n. 40/MD de 23 de junho de 2016. Aprova a Doutrina de Logística Militar (MD 42-M-02, 3. ed.). Brasília: Estado-Maior Conjunto das Forças Armadas.

Burkle Junior, F. M. (2005). Anatomy of an ambush: security risks facing international humanitarian assistance. Disasters, 29(1), $26-37$. http://dx.doi.org/10.1111/j.0361-3666.2005.00272.x. PMid:15720379.

Costa, N. B. O. L., Fontainha, T. C., \& Leiras, A. (2017). Brazilian Air Force operations in disaster response - a process analysis. Disaster Prevention and Management: An International Journal, 26(4), 479-498. http://dx.doi.org/10.1108/DPM-04-2017-0081.

Eriksson, K. (2009). Knowledge transfer between preparedness and emergency response: a case study. Disaster Prevention and Management: An International Journal, 18(2), 162-169. http://dx.doi.org/10.1108/09653560910953234.

Fontainha, T. C., Leiras, A., Bandeira, R. A. M., \& Scavarda, L. F. R. R. (2017). Public-private-people relationship stakeholder model for disaster and humanitarian operations. International Journal of Disaster Risk Reduction, 22, 371-386. http://dx.doi.org/10.1016/j. ijdrr.2017.02.004.

Guha-Sapir D., Hoyois P. H., Wallemacq P., Below, R. (2017). Annual disaster statistical review 2016: the numbers and trends. Brussels: Cred.

Haiti Grassroots Watch. (2011). Haiti Earthquake - by the numbers. Retrieved in 20 February 2017, from http://haitigrassrootswatch. squarespace.com/5chiffresen

Heaslip, G., \& Barber, E. (2014). Using the military in disaster relief: systemising challenges, and opportunities. Journal of Humanitarian Logistics and Supply Chain Management, 4(1), 60-81. http://dx.doi.org/10.1108/JHLSCM-03-2013-0013.

Leaning, J., Briggs, S., \& Chen, L. C., (1999). Humanitarian crises: the medical and public health response. Cambridge: Havard University Press.

Leiras, A., Brito Junior, I. B., Peres, E. Q., Bertazzo, T. R., \& Yoshizaki, H. T. Y. (2014). Literature review of humanitarian logistics research: trends and challenges. Journal of Humanitarian Logistics and Supply Chain Management, 4(1), 95-130. http://dx.doi.org/10.1108/ JHLSCM-04-2012-0008. 
Mora, P., \& Brain, 1. (2013). Chile antes e depois da catástrofe: alguns dados cruciais para analisar os desafios da reconstrução. Gerência de Riscos e Seguros, XXX(116), 74-88. Retrieved in 20 February 2017, from http://doczz.com.br/doc/198091/no-116-segundoquadrimestre-2013

Oloruntoba, R. (2010). An analysis of the Cyclone Larry emergency relief chain: some key success factors. International Journal of Production Economics, 126(1), 85-101. http://dx.doi.org/10.1016/j.jpe.2009.10.013.

Organizacion Panamericana de la Salud. (2010). El terremoto y tsunami del 27 de febrero em Chile. Cronica y lecciones aprendidas em el sector salud. Santiago: OPAS. Retrieved in 20 February 2017, from http://www1.paho.org/chi/images/PDFs/terremoto101125094619-phpapp02.pdf

Pettit, S. J., \& Beresford, A. K. C. (2005). Emergency relief logistics: an evaluation of military, non-military, and composite response models. International Journal of Logistics: Research and Applications, 8(4), 313-331. http://dx.doi.org/10.1080/13675560500407325.

Phillips, M. (2011, November). The role of the military in international disaster relief activities. In International Symposium on Security Affairs 2011 (pp. 33-43). Tóquio. 2011. Retrieved in 20 February 2017, from http://www.nids.mod.go.jp/english/event/symposium/ pdf/2011/e_03.pdf

Pinto, E. G. (2010). Telerradiolgia no sistema de saúde da marinha: necessidades e aplicação (Monografia). Escola de Guerra Naval, Rio de Janeiro. Retrieved in 06 June 2018, from https://www.egn.mar.mil.br/arquivos/biblioteca/monografias/cpem/2010/027\%20 CMG(Md)\%20GONÇALVES\%20PINTO.pdf

Tatham, P., \& Rietjens, S. B. (2016). Integrated disaster relief logistics: a stepping stone towards viable civil-military networks? Disasters, 4O(1), 7-25. http://dx.doi.org/10.1111/disa.12131. PMid:26271356.

United Nations. (2009). International strategy for disaster reduction: terminology. Genebra: UNISDR. Retrieved in 20 February 2017 from https://www.unisdr.org/we/inform/publications/7817

United States Geological Survey. (2011). Report on the 2010 Chilean earthquake and tsunami response. Reston: USGS. Retrieved from https://pubs.usgs.gov/of/2011/1053/of2011-105C3.pdf

Van Wassenhove, L. N. (2006). Blackett memorial lecture, humanitarian aid logistics: supply chain management in high gear. The Journal of the Operational Research Society, 576), 475-489. http://dx.doi.org/10.1057/palgrave.jors.2602125.

Vilela, F. F. (2015). O emprego da Marinha do Brasil na ajuda humanitária: capacidades e limitações (Monografia). Escola de Guerra Naval, Rio de Janeiro.

Weeks, M. (2007). Organizing for disaster: lessons from the military. Business Horizons, 50(6), 479-489. http://dx.doi.org/10.1016/j bushor.2007.07.003.

Yanez, R. (2012). O novo papel das forças armadas chilenas em caso de desastres naturais (Monografia). Escola de Guerra Naval, Rio de Janeiro.

Yin, R. K. (2013). Case study research: design and methods (5th ed.). Thousand Oaks: Sage Publications. 